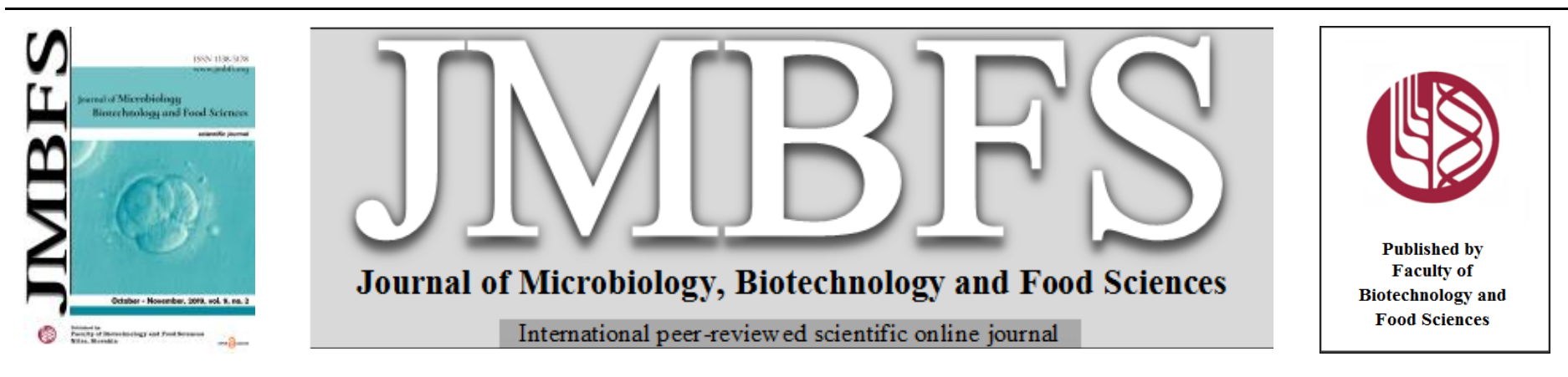

\title{
BACTERIA MAY DETERIORATE PROGRESSIVE MOTILITY OF BOVINE SPERMATOZOA AND BIOCHEMICAL PARAMETERS OF SEMINAL PLASMA
}

\author{
Michal Ďuračka*l, Anton Kováčik ${ }^{l}$, Miroslava Kačániová ${ }^{2}$ Norbert Lukáčl, Eva Tvrdál
}

Address(es): MSc. Michal Ďuračka,

${ }^{1}$ Slovak University of Agriculture in Nitra, Faculty of Biotechnology and Food Sciences, Department of Animal Physiology, Tr. A. Hlinku 2, 94976 Nitra, Slovakia.

${ }^{2}$ Slovak University of Agriculture in Nitra, Faculty of Horticulture and Landscape Engineering, Department of Fruit Science, Viticulture and Enology, 94976 Nitra, Slovakia.

*Corresponding author: michaelduracka@ gmail.com

doi: 10.15414/jmbfs.2020.9.4.844-847

\section{ARTICLE INFO}

Received 15. 8. 2019

Revised 8. 10. 2019

Accepted 23. 10. 2019

Published 3. 2. 2020

Regular article open $\partial_{\text {ACCESS }}$

\begin{abstract}
Bacterial contamination of ejaculates has captured the interest of the wide andrological community. Interactions between spermatozoa and bacteria are partially known. The aim of our study was to evaluate qualitative bacterial composition of fresh bovine semen and to reveal associations amongst the quantity of bacteria (Colony Forming Unit - CFU/mL) present in bovine ejaculates with progressive motility of spermatozoa and biochemical parameters of seminal plasma. Fresh semen $(n=20)$ was collected from Holstein-Friesian bulls. Progressive motility (PROG $\geq 25 \mu \mathrm{m} / \mathrm{s}$ ) was analysed using Computer-assisted sperm analysis (CASA). Seminal plasma was separated and subjected to assessment (Randox RX Monza analyzer) of following biochemical parameters: Magnesium (Mg), Calcium (Ca), Phosphor (P), Urea, Aspartate transaminase (AST), Alanine transaminase (ALT), Alkaline phosphatase (ALP), Cholesterol, Bilirubin, Triglycerides, Albumin and Uric acid. The identification of bacteria showed the prevalence of the genus Staphylococcus. The Pearson correlation analysis showed a negative significant $(\mathrm{P}<0.001)$ correlation between $\mathrm{CFU}$ and PROG. Further, positive significant correlations were observed amongst PROG and biochemical parameters ( $\mathrm{P}<0.01$ in case of Mg, Urea, ALP, ALB; $\mathrm{P}<0.05$ in case of Ca, ALT, Bilirubin and Uric acid). The results show negative significant correlations amongst CFU and biochemical parameters $(\mathrm{P}<0.001$ in case of Mg; $\mathrm{P}<0.01$ in case of ALT, ALP and $\mathrm{P}<0.05$ in case of Uric acid). In conclusion, our results reveal that bacteria may affect not only on the sperm motility, but also on the composition of the seminal plasma. More detailed studies are needed to reveal the mechanisms of interaction amongst semen and bacteria.
\end{abstract}

Keywords: spermatozoa, bacteria, biochemical parameters, progressive motility, seminal plasma

\section{INTRODUCTION}

Artificial insemination (AI) represents the result of high economic pressure and simultaneously the highest possible milk production. The cryopreservation of semen samples is one of the attractive advances in current AI programs. Unfortunately, cryopreservation possesses a high risk related to bacterial contamination of ejaculates (Sannat $\boldsymbol{e t}$ al., 2015). Ubiquitous microbes have ample chances to contaminate samples during collection, processing and storage. Despite sterilization, artificial vagina, glassware and accessories, extender or laboratory environment are the most common sources of bacterial contamination of samples during processing (Rana et al., 2012). Obviously, bacteria are present under physiological or pathological conditions in the ejaculate. Bacteria may contaminate the ejaculate all way from the testes, through epididymis, vas deferens, accessory glands to urethral opening and foreskin (Marcus et al., 1994). The use of a microbiologically active insemination dose may not only reduce birth rate, but also transmit diseases amongst healthy populations (Thibier and Guerin, 2000). Based on previous studies, bacteria can induce oxidative stress in spermatozoa and damage sperm membranes, which may lead to subfertility. Some bacterial strains may cause the agglutination of motile sperm, leading to the premature acrosomal reaction and morphological alterations of the sperm head. Moreover, the inflammatory response inside the genitourinary tract leads to increased level of leukocytes and this is reflected in the increased reactive oxygen species (ROS) generation (Moretti $\boldsymbol{e t}$ al. 2009; Sabeti $\boldsymbol{e}$ t al., 2016). Although, the studies above reported that bacteria may damage the sperm cells, there is no available information about the effect of the presence of bacteria on the seminal plasma. Therefore, the aim of this study was to determine composition of bacterial load in fresh bovine ejaculates and to correlate bacterial load with progressive motility of spermatozoa and with levels of selected biochemical parameters in seminal plasma.

\section{MATERIAL AND METHODS}

\section{Semen collection and processing}

Ejaculates $(n=20)$ were obtained from sexually mature healthy Holstein-Friesian breeding bulls using an artificial vagina (Slovak Biological Services, a. s., Lužianky, Slovakia). The samples were transported to the laboratory within 15 minutes in thermos due to keeping a constant temperature. Immediately upon arrival, $100 \mu \mathrm{L}$ of each sample were aliquoted in test-tubes and stored at $-20^{\circ} \mathrm{C}$ for the microbiological assessment. Only samples with a minimum of $70 \%$ motility and $1 \times 10^{9} \mathrm{sperm} / \mathrm{mL}$ were used for further experiments to meet the quality criteria given for the corresponding breed.

\section{Progressive motility assessment}

The computer-assisted sperm analysis (CASA; Version 14.0 TOX IVOS II; Hamilton-Thorne Biosciences, Beverly, MA, USA) was used to determine progressive motility. Samples were diluted in physiological saline solution (PS; sodium chloride $0.9 \% \mathrm{w} / \mathrm{v}$, Bieffe Medital Grosotto, Italia) in a dilution ratio of 1:40. Subsequently, $10 \mu \mathrm{L}$ of each sample were placed into the Makler counting chamber (depth $10 \mu \mathrm{m}, 37^{\circ} \mathrm{C}$; Sefi Medical Instruments, Haifa, Israel) and progressive motility of spermatozoa was assessed in 10 fields at a minimum 30 cells per field. Progressive motility of spermatozoa is determined by a velocity of $\geq 25 \mu \mathrm{m} / \mathrm{s}$.

\section{Cultivation and identification of bacteria}

One hundred $\mu \mathrm{L}$ of each sample were cultured in the blood agar, Gassner agar and Tryptic soy agar. The cultures were maintained at $37{ }^{\circ} \mathrm{C}$ during $24-48 \mathrm{~h}$ under aerobic conditions. The quantity of bacteria was evaluated by counting 
Colony Forming Units (CFU/mL). Purification of all microorganisms was done by four ways streak plate method after the first cultivation.

Qualitative bacterial analysis of semen samples was performed by Matrixassisted laser desorption ionization - time of flight (MALDI-TOF MS; Bruker Daltonics, Germany). Fresh overnight isolates were prepared in accordance to the manufacturer's recommendations using the ethanol-formic acid extraction method. Sample spots were overlaid with $2 \mu \mathrm{L}$ of matrix solution (saturated solution of $\alpha$-cyano-4-hydroxycinnamic acid in 50\% acetonitrile and $2.5 \%$ trifluoroacetic acid) and left to dry for $15 \mathrm{~min}$ in room temperature. Raw spectra of each isolate were compared to a spectra database in Biotyper software (version 2.0; Bruker Daltonics, Germany) without any user intervention (Hleba $\boldsymbol{e t}$ al. 2017).

\section{Biochemical analysis}

Magnesium (Mg), Calcium (Ca), Phosphor (P), Urea (U), Aspartate transaminase (AST), Alanine transaminase (ALT), Alkaline phosphatase (ALP), Cholesterol (CHOL), Bilirubin (BILI), Triglycerides (TG), Albumin (ALB) and Uric acid (UA) were measured using the commercial kits DiaSys (Diagnostic Systems GmbH, Holzheim, Germany) on the Randox RX Monza analyzer (Crumlin, United Kingdom) (Kováčik et al., 2017).

\section{Statistical analysis}

All data were subjected to statistical analysis using the GraphPad Prism program (version 6.0 for Windows, GraphPad Software incorporated, San Diego, California, USA, http://www.graphpad.com/). Results of the mean quality parameters of ejaculate are quoted as arithmetic mean $(\mathrm{AM}) \pm$ standard deviation (SD). Pearson correlation coefficient analysis for paired samples was used to evaluation of correlations between the quantity of bacterial CFU and quality parameters of semen. The level of significance for the correlation analysis was set at $* * *(\mathrm{P}<0.001) ; * *(\mathrm{P}<0.01) ; *(\mathrm{P}<0.05)$.

\section{RESULTS AND DISCUSSION}

\section{Mean values of sperm quality parameters}

In this study we assessed the relationship amongst bacterial load and their interactions with progressive motility and biochemical parameters in seminal plasma of bovine ejaculates. Mean values of progressive motility, CFU and biochemical parameters are displayed in Table 1.

Table 1 Mean values of progressive motility, bacterial load and biochemical parameters

\begin{tabular}{lccccccc}
\hline PARAMETER & $\begin{array}{c}\text { PROG } \\
{[\%]}\end{array}$ & $\begin{array}{c}\text { CFU } \\
{[\log \mathrm{CFU} / \mathrm{g}]}\end{array}$ & $\begin{array}{c}\mathbf{C a} \\
{[\mathrm{mM} / \mathrm{L}]}\end{array}$ & $\begin{array}{c}\mathbf{P} \\
{[\mathrm{mM} / \mathrm{L}]}\end{array}$ & $\begin{array}{c}\mathbf{M g} \\
{[\mathrm{mM} / \mathrm{L}]}\end{array}$ & $\begin{array}{c}\mathbf{U} \\
{[\mathrm{mM} / \mathrm{L}]}\end{array}$ & $\begin{array}{c}\text { UA } \\
{[\mathrm{mg} / \mathrm{dL}]}\end{array}$ \\
\hline VALUE & 66.83 & 2.70 & 6.81 & 3.22 & 3.78 & 1.12 & 1.72 \\
S. D. & 7.59 & 3.10 & 0.85 & 0.58 & 0.60 & 0.27 & 0.30 \\
\hline PARAMETER & $\mathbf{A S T}$ & $\mathbf{A L T}$ & $\mathbf{A L P}$ & $\mathbf{C H O L}$ & $\mathbf{B I L I}$ & $\mathbf{T G}$ & $\mathbf{A L B}$ \\
& {$[\mu \mathrm{kat} / \mathrm{L}]$} & {$[\mu \mathrm{kat} / \mathrm{L}]$} & {$[\mu \mathrm{kat} / \mathrm{L}]$} & {$[\mathrm{mM} / \mathrm{L}]$} & {$[\mu \mathrm{M} / \mathrm{L}]$} & {$[\mathrm{mM} / \mathrm{L}]$} & {$[\mathrm{g} / \mathrm{dL}]$} \\
\hline VALUE & 0.13 & 1.11 & 70.86 & 1.70 & 14.35 & 0.43 & 1.42 \\
S. D. & 0.07 & 0.21 & 11.24 & 0.38 & 2.49 & 0.06 & 0.22 \\
\hline Legend: PROG - progressive motility, CFU - colony forming units, Ca - calcium, P - phosphorus, Mg - magnesium, U - urea, \\
AST - aspartate transaminase, ALT - alanine transaminase, ALP - alkaline phosphatase, CHOL - cholesterol, BILI - bilirubin, \\
TG - triglycerides, ALB - albumin, UA - uric acid.
\end{tabular}

Juyena and Stelleta (2013) analysed basic biochemical parameters in bovine seminal plasma. In comparison to their study, results of our measurements were similar with respect to $\mathrm{Ca}, \mathrm{P}$ and $\mathrm{Mg}$. In accordance to Navya's (2012) results, the mean bacterial load in the neat semen from Holstein-Friesian bulls was $4.51 \pm 0.87 \log \mathrm{CFU} / \mathrm{mL}$ which was in accordance to our measurements of bacterial load in semen. Cholesterol concentration in the seminal plasma was determined to be $1.70 \pm 0.38 \mathrm{mmol} / \mathrm{L}$, which was several times higher in comparison to other reports. Concentration of UA was determined to be $1.12 \pm 0.27 \mathrm{mg} / \mathrm{dL}$, which was much lower when compared to our results. On the other hand, there were increased concentrations of TG $(0.43 \pm 0.06 \mathrm{mmol} / \mathrm{L})$ and $\mathrm{U}(1.12 \pm 0.27)$ in our samples when compared to Cevik's et al. (2007) report. The mean bilirubin and albumin concentrations are consistent with the results obtained in a previous study (Tvrdá et al., 2013).

Table 2 Identification and quantification of bacterial colonies $[\log \mathrm{CFU} / \mathrm{mL}]$ in bovine ejaculates isolated on different culture media

\begin{tabular}{lcccc}
\hline Sample no. & Blood agar & Gassner agar & TSA & Identified bacteria \\
\hline $\mathbf{1}$ & 2.00 & $\mathrm{n}$ & $\mathrm{n}$ & B. cereus \\
$\mathbf{3}$ & $\mathrm{n}$ & $\mathrm{n}$ & 2.70 & S. cohnii, S. kloosii \\
$\mathbf{8}$ & 2.30 & $\mathrm{n}$ & 2.70 & S. cohnii, S. kloosii, B. cereus, M. luteus \\
$\mathbf{9}$ & 2.70 & $\mathrm{n}$ & 2.48 & B. cereus, B. licheniformis \\
$\mathbf{1 1}$ & 3.18 & $\mathrm{n}$ & 3.41 & S. xylosus, S. aureus, S. warneri, S. lentus, S. epidermis, B. mycoides \\
$\mathbf{1 2}$ & 2.48 & $\mathrm{n}$ & 2.30 & B. cereus \\
$\mathbf{1 3}$ & 3.08 & $\mathrm{n}$ & 3.11 & S. cohnii, S. kloosii \\
$\mathbf{1 4}$ & 2.30 & $\mathrm{n}$ & 2.48 & S. kloosii \\
$\mathbf{1 7}$ & $\mathrm{n}$ & 2.00 & 2.00 & S. aureus, S. haemolyticus \\
$\mathbf{2 0}$ & $\mathrm{n}$ & $\mathrm{n}$ & 2.30 & S. aureus, S. haemolyticus
\end{tabular}

In 10 semen samples out of 20 we identified bacteria on the selected growth media. Amongst the colonies isolated from bovine ejaculates, we have identified the following bacteria: Bacillus cereus, Staphylococcus cohnii, Staphylococcus klosii, Micrococcus luteus, Bacillus licheniformis, Staphylococcus xylosus, Staphylococcus aureus, Staphylococcus warneri, Staphylococcus lentus, Staphylococcus epidermidis, Bacillus mycoides and Staphylococcus haemolyticus. Zampieri et al. (2013) reported that the MALDI-TOF method is as exact as quick. The accuracy of this technique was proven by the DNA sequencing of bacterial strains isolated from bovine ejaculates. Last available report targeting on the identification of bacteria in bovine ejaculates proven the prevalence of species from genus Staphylococcus, mainly S. aureus (16\%), S intermedius (11\%), S. coagulase-negative ( $8 \%)$, S. epidermidis $(10 \%)$. Moreover,
Escherichia coli sp. (16\%), Pseudomonas aeruginosa (13\%), Pseudomonas putida (2\%), Pseudomonas testosteroni (4\%), Micrococcus sp. (11\%), Proteus mirabilis $(6 \%)$, and Bacillus sp. (4\%) were identified in ejaculates of buffalo bulls (Andrabi et al., 2016). An older study reported the occurrence of the genus Porphyrmonas, Staphylococcus ssp., Lactobacillus ssp., Peptostreptococcus anaerobius, Streptococcus mitis, Alcaligenes faecalis, Neiseria weaveri, Haemophilus infuenzae, Acinetobacter junii and Pseudomonas putida in ejaculates obtained from Holstein bulls (González-Marín et al., 2011). Several previous studies have proven deleterious effects of bacterial load on quality of spermatozoa (Enwuru et al., 2016; Ďuračka and Tvrdá, 2018). However, there is no evidence about their effect on the composition of seminal plasma.

Table 3 Correlation analysis expressed through Pearson's correlation coefficient (r) amongst progressive motility, CFU and biochemical parameters

\begin{tabular}{lccccccccccccc}
\hline & PROG & Ca & P & Mg & AST & ALT & ALP & CHOL & TG & BILI & ALB & U & UA \\
CFU & $-0.736^{* * *}$ & -0.264 & -0.263 & $-0.921^{* * *}$ & -0.206 & $-0.568^{* *}$ & $-0.667 * *$ & -0.268 & -0.122 & -0.031 & -0.305 & -0.222 & $-0.397 *$ \\
PROG & 1 & $0.348^{*}$ & 0.206 & $0.592 * * *$ & 0.389 & $0.553^{*}$ & $0.837 * *$ & 0.492 & 0.270 & $0.657 *$ & $0.626 * *$ & $0.651 * *$ & $0.572^{*}$ \\
\hline
\end{tabular}

Legend: PROG - progressive motility, CFU - colony forming units, Ca - calcium, P - phosphorus, Mg - magnesium, U - urea, AST - aspartate transaminase, ALT - alanine transaminase, ALP - alkaline phosphatase, CHOL - cholesterol, BILI - bilirubin, TG - triglycerides, ALB - albumin, UA - uric acid; *** $-\mathrm{P}<0.001 ; * *-\mathrm{P}<0.01 ; *-\mathrm{P}<0.05$. 
In our study, the correlation analysis confirmed detrimental effect of bacterial load on the progressive motility of bovine spermatozoa, as there was strong negative $(-0.736)$ and statistically significant $(\mathrm{P}<0.001)$ correlation between PROG and CFU. Moretti et al. (2009) verified the prevalence of bacteria in human semen samples and the potential relationship with sperm quality. They pointed out that 86 men out of 230 men included in their study were considered fertile despite the fact that their semen samples were positive for various bacteria: E. faecalis, E. coli, S. agalactiae, U. urealyticum, S. epidermidis, S. anginosus, M. morganii. Except for the samples containing S. agalactiae and S. anginosus, the progressive motility was decreased when compared to WHO guidelines and significantly decreased when compared to controls. Apparently, an important role in the sperm quality may play hemolysin, a well-known virulence factor of enterococci and staphylococci (Moretti et al., 2009; Pontieri, 2018). The bacterial flagella and pili are considered to be an important determinant of pathogenicity. The mechanism of the bacterial damage of spermatozoa comes from the expression of the adhesive properties of the flagella and pili to mannose receptors at the surface of spermatozoa. Subsequently, the production of metabolic products and toxins originating from bacterial proliferation are in the direct contact with the sperm membrane (Villegas et al., 2005; Moretti et al., 2009). The correlation analysis revealed very strong (-0.921) and significan $(\mathrm{P}<0.001)$ correlation between $\mathrm{Mg}$ concentration and $\mathrm{CFU}$. Vice versa, significant positive correlation $(0.592 ; \mathrm{P}<0.001)$ was observed between $\mathrm{Mg}$ concentration and PROG. As Mg is essential element during production of ATP decreased concentration of $\mathrm{Mg}$ may be ultimately responsible for decreased sperm motility (Valsa et al., 2013). An important role in sperm metabolism play transaminases and phosphatases. Considering that $\mathrm{Mg}$ is essential element in spermiogenesis and as a cofactor in enzymatic reactions may $\mathrm{Mg}$ affect activity of these enzymes. In current study was observed negative correlation $(\mathrm{P}<0.01)$ amongst activity of ALT (-0.568), ALP (-0.667) and CFU, which may be related to level of Mg in seminal plasma. Yousef et al. (2007) reported that the decrease in the activities of seminal plasma enzymes (AST, ALT) coincided with the decrease of semen quality. Therefore, the authors are in consensus that the presence of bacteria in semen may indirectly affect activity of transaminases through concentration of $\mathrm{Mg}$ in seminal plasma. A previous study (Meena et al., 2015) suggested that microbial contamination had an effect not only on the morphology, motility and quality parameters of spermatozoa, but also on the nutrient composition of seminal plasma. Considering that bacteria may compete for nutrients amongst each other (Hibbing et al., 2010), synergic effect of various opportunistic pathogenic bacteria may completely deprive nutrients in the seminal plasma. The role of ALP in semen is to catalyse the transport of phosphate groups into spermatozoa. Thereby, ALP contributes to processes associated with fertilization. A decreased ALP activity may be caused by infection of the epididymis. Moreover, a decreased ALP activity was correlated with a decreased spermatozoa concentration in various animal species (Mollo $\boldsymbol{e}$ al., 1997; Pesch et al., 2006; Schäfer-Somi et al., 2013). Despite that previous study did not consider albumin as a dominant protein (Chard et al., 1991), our study revealed its significant correlation $(0.626 ; \mathrm{P}<0.01)$ with PROG. This correlation may be explained through its multiple-binding sites and free radicaltrapping properties (Tvrdá et al., 2013). Although we expected a significant correlation between $\mathrm{Ca}$ and $\mathrm{CFU}$, only a weak negative correlation $(-0.264)$ was observed. On the other hand, significant correlation $(0.348 ; \mathrm{P}<0.05)$ was observed between $\mathrm{Ca}$ and PROG. According to Rahman et al. (2014) Ca uptake is associated with the entire process of fertilization - from hyperactivation, chemotaxis, capacitation to the acrosome reaction and reaching an oocyte. Concentration of UA reflected in both, CFU and PROG. While the correlation with PROG was significant $(\mathrm{P}<0.05)$ and positive $(0.572)$, the correlation with CFU was significant $(\mathrm{P}<0.05)$ and negative $(-0.397)$. This phenomenon may be explained through potent antioxidative properties of UA. From the studies above it is apparent that various bacterial species may produce free radicals. On one hand, UA may scavenge hydroxyl radicals. On the other hand, UA converts to U which, according to several studies (Allahkarami et al., 2017; Halo Jr. et al., 2018), may be related to a decreased sperm motility, which is in conflict with our results. The correlation analysis revealed significant $(\mathrm{P}<0.01)$ and positive (0.651) correlation between PROG and $\mathrm{U}$.

\section{CONCLUSION}

Our study investigated the bacterial composition of fresh semen from healthy Holstein-Friesian breeding bulls. The results of bacterial identification showed the prevalence of species from Staphylococcus genus, mainly $S$. aureus, $S$. haemolyticus, S. epidermidis, S. cohnii and S. kloosii. Furthermore, B. cereus B. licheniformis, M. luteus, B. mycoides, S. xylosus and S. warneri were identified in fresh semen. The second part of our study dealt with associations amongst bacterial load present in ejaculates, progressive motility of spermatozoa and biochemical composition of seminal plasma. The correlation analysis revealed strong negative association between bacterial load and concentration of $\mathrm{Mg}$. The decreased amount of Mg may affect the activity of ALP and ALT. Furthermore, strong negative correlation was observed between progressive motility of spermatozoa and bacterial load. Therefore, we may conclude that the bacterial load may modulate the seminal plasma composition which may lead to an impaired nutrition for spermatozoa. Further studies are needed to understand deeply the mechanisms behind the effects of bacteria on spermatozoa.

Acknowledgements: This study was supported by the European Community Project no. 26220220180: Building Research Centre „AgroBioTech“, by the Scientific Grant Agency of the Ministry of Education of the Slovak Republic and by the Slovak Research and Development Agency Project no. APVV-15-0544.

\section{REFERENCES}

Allahkarami, S., Atabakhsh, M., Moradi, M. N., Ghasemi, H., Bahmanzadeh, M., \& Tayebinia, H. (2017). Correlation of uric acid, urea, ammonia and creatinine of seminal plasma with semen parameters and fertilization rate of infertile couples. Avicenna Journal of Medical Biochemistry, 5(2), 76-80 https://doi.org/10.15171/ajmb.2017.14

Andrabi, S. M. H., Khan, L. A., \& Shahab, M. (2016). Isolation of bacteria in semen and evaluation of antibiotics in extender for cryopreservation of buffalo (Bubalus bubalis) bull spermatozoa. Andrologia, 48(10), 1166-1174. https://doi.org/10.1111/and.12555

Çevik, M., Tuncer, P. B., TASSDEMIR, U., \& Özgürtaș, T. (2008). Comparison of spermatological characteristics and biochemical seminal plasma parameters of normozoospermic and oligoasthenozoospermic bulls of two breeds. Turkish Journal of Veterinary and Animal Sciences, 31(6), 381-387.

Chard, T., Parslow, J., Rehmann, T., \& Dawnay, A. (1991). The concentrations of transferrin, beta 2-microglobulin, and albumin in seminal plasma in relation to sperm count. Fertility and sterility, 55(1), 211-213. https://doi.org/10.1016/S0015-0282(16)54087-4

Duračka, M., \& Tvrda, E. (2018). 504 The presence of bacterial species in boar semen and their impact on the sperm quality and oxidative balance. Journal of Animal Science, 96(suppl_3), 501-501. https://doi.org/10.1093/jas/sky404.1094

Enwuru, C. A., Iwalokuna, B., Enwuru, V. N., Ezechi, O., \& Oluwadun, A. (2016). The effect of presence of facultative bacteria species on semen and sperm quality of men seeking fertility care. African journal of urology, 22(3), 213-222. https://doi.org/10.1016/j.afju.2016.03.010

González-Marín, C., Roy, R., López-Fernández, C., Diez, B., Carabaño, M. J., Fernández, J. L., Kjelland, M. E., Moreno, J. F., \& Gosálvez, J. (2011). Bacteria in bovine semen can increase sperm DNA fragmentation rates: A kinetic experimental approach. Animal reproduction science, 123(3-4), 139-148. https://doi.org/10.1016/j.anireprosci.2010.11.014

Halo Jr, M., Tirpák, F., Kováčik, A., Lípová, P., Greń, A., \& Massányi, P. (2018). BIOCHEMICAL PARAMETERS OF SEMINAL PLASMA AFFECT MOTILITY TRAITS OF STALLION SPERMATOZOA. The Journal of Microbiology, Biotechnology and Food Sciences, 7(5), 516-518. https://doi.org/10.15414/jmbfs.2018.7.5.516-518

Hibbing, M. E., Fuqua, C., Parsek, M. R., \& Peterson, S. B. (2010). Bacterial competition: surviving and thriving in the microbial jungle. Nature reviews. Microbiology, 8(1), 15-25. https://doi.org/10.1038/nrmicro2259

Hleba, L., Kmet', V., Tóth, T., \& Kačániová, M. (2017). Resistance in bacteria and indirect beta-lactamase detection in E. coli isolated from Culex pipiens detected by matrix-assisted laser desorption ionization time of flight mass spectrometry. Journal of Environmental Science and Health, Part B, 52(1), 64 69. https://doi.org/10.1080/03601234.2016.1229466

Juyena, N. S., \& Stelletta, C. (2012). Seminal plasma: an essential attribute to spermatozoa. Journal of andrology, 33(4), 536-551. https://doi.org/10.2164/jandrol.110.012583

Kováčik, A., Árvay, J., Tušimová, E., Harangozo, L., Tvrdá, E., Zbyňovská, K., Čupka, P., Andrašč́ková, S., Tomáš, J., \& Massányi, P. (2017). Seasonal variations in the blood concentration of selected heavy metals in sheep and their effects on the biochemical and hematological parameters. Chemosphere, 168 365-371. https://doi.org/10.1016/j.chemosphere.2016.10.090

Marcus, S., Bernstein, M., Ziv, G., Glickman, A., \& Gipps M. (1994). Norfloxacin nicotinate in the treatment of Pseudomonas aeruginosa infection in the genital tract of a bull. Veterinary Research Communications, 18(5), 331-336. https://doi.org/10.1007/BF01839283

Meena, G. S., Raina, V. S., Gupta, A. K., Mohanty, T. K., Bhakat, M., Abdullah, M., \& Bishist, R. (2015). Effect of preputial washing on bacterial load and preservability of semen in Murrah buffalo bulls. Veterinary world, 8(6), 798-803. https://doi.org/10.14202/vetworld.2015.798-803

Mollo, A., Bosisio, P., Avezza, F., \& Luvoni, G. C. (1997). Concentrazione della fosfatasi alcalina nel plasma seminale del cane. In Convegno nazionale SISVet (Vol. 51, pp. 171-172). Società italiana delle scienze veterinarie.

Moretti, E., Capitani, S., Figura, N., Pammolli, A., Federico, M. G., Giannerini, V., \& Collodel, G. (2009). The presence of bacteria species in semen and sperm quality. Journal of assisted reproduction and genetics, 26(1), 47-56. https://doi.org/10.1007/s10815-008-9283-5

Navya, M. (2012). Bacterial load in the neat, extended and frozen bull semen and its antibiogram (Doctoral dissertation, Karnataka Veterinary, Animal and Fisheries Sciences University, Bidar).

Pesch, S., Bergmann, M., \& Bostedt, H. (2006). Determination of some enzymes and macro-and microelements in stallion seminal plasma and their correlations to 
semen quality. Theriogenology, 66(2),

307-313.

https://doi.org/10.1016/i.theriogenology.2005.11.015

Pontieri, E. (2018). The Staphylococcal Hemolysins. In Pet-To-Man Travelling Staphylococci (pp. 103-116). Academic Press. https://doi.org/10.1016/B978-0 12-813547-1.00008-X

Rahman, M. S., Kwon, W. S., \& Pang, M. G. (2014). Calcium influx and male fertility in the context of the sperm proteome: an update. BioMed research international, 2014. http://dx.doi.org/10.1155/2014/841615

Rana, N., Vaid, R. K., Phulia, S. K., \& Singh, P. (2012). Assessment of bacterial diversity in fresh bubaline semen. Indian Journal of Animal Sciences, 82(6), 596598

Sabeti, P., Pourmasumi, S., Rahiminia, T., Akyash, F., \& Talebi, A. R. (2016) Etiologies of sperm oxidative stress. International journal of reproductive biomedicine (Yazd, Iran), 14(4), 231-240. https://doi.org/10.29252/ijrm.14.4.231 Sannat, C., Nair, A., Sahu, S. B., Sahasrabudhe, S. A., Kumar, A., Gupta, A. K. \& Shende, R. K. (2015). Effect of species, breed, and age on bacterial load in bovine and bubaline semen. Veterinary world, 8(4), 461-466. http://dx.doi.org/10.14202/vetworld.2015.461-466

Schäfer-Somi, S., Fröhlich, T., \& Schwendenwein, I. (2013). Measurement of alkaline phosphatase in canine seminal plasma-an update. Reproduction in domestic animals, 48(1), e10-e12. $\quad$ https://doi.org/10.1111/j.14390531.2012.02025.x

Thibier, M., \& Guerin, B. (2000). Hygienic aspects of storage and use of semen for artificial insemination. Animal Reproduction Science, 62(1-3), 233-251. https://doi.org/10.1016/S0378-4320(00)00161-5

Tvrdá, E., Lukáč, N., Schneidgenová, M., Lukáčová, J., Szabó, C., Goc, Z., Greń A., \& Massányi, P. (2013). Impact of Seminal Chemical Elements on the Oxidative Balance in Bovine Seminal Plasma and Spermatozoa. Journal of veterinary medicine, 2013, 125096. https://doi.org/10.1155/2013/125096

Valsa, J., Skandhan, K. P., Gusani, P. H., Sahab Khan, P., \& Amith, S. (2013). Quality of 4-hourly ejaculates-levels of calcium and magnesium. Andrologia , 45(1), 10-17. $\quad$ https://doi.org/10.1111/j.14390272.2012.01301.x

Villegas, J., Schulz, M., Soto, L., \& Sanchez, R. (2005). Bacteria induce expression of apoptosis in human spermatozoa. Apoptosis, 10(1), 105-110. https://doi.org/10.1007/s10495-005-6065-8

Yousef, M. I., Kamel, K. I., El-Guendi, M. I., \& El-Demerdash, F. M. (2007). An in vitro study on reproductive toxicity of aluminium chloride on rabbit sperm: the protective role of some antioxidants. Toxicology, 239(3), 213-223. https://doi.org/10.1016/j.tox.2007.07.011

Zampieri, D., Santos, V. G., Braga, P. A., Ferreira, C. R., Ballottin, D., Tasic, L. Basso, A. C., Sanches, B. V., Pontes, J. H. F., da Silva, B. P., Garboggini, F. F. Eberlin, M. N., \& Tata, A. (2013). Microorganisms in cryopreserved semen and culture media used in the in vitro production (IVP) of bovine embryos identified by matrix-assisted laser desorption ionization mass spectrometry (MALDIMS). Theriogenology, 80(4),

https://doi.org/10.1016/j.theriogenology.2013.04.020

337-345. 